\title{
Morphological alterations in salivary glands of mice (Mus musculus) submitted to tannin enriched diets: comparison with sialotrophic effects of sympathetic agonists stimulation
}

\author{
[Alterações morfológicas das glândulas salivares de camundongos (Mus musculus) submetidos a dietas \\ enriquecidas com taninos: comparação com os efeitos sialotróficos da estimulação \\ com agonistas do sistema nervoso simpático] \\ E. Lamy $^{1}$, E.S. Baptista ${ }^{1,2}$, A.V. Coelho ${ }^{3,4}$, F. Capela e Silva $a^{1,5^{*}}$ \\ ${ }^{1}$ Instituto de Ciências Agrárias e Ambientais Mediterrânicas (ICAAM) - Universidade de Évora, Portugal \\ ${ }^{2}$ Departamento de Zootecnia - Universidade de Évora, Portugal \\ ${ }^{3}$ Instituto de Tecnologia Química e Biológica (ITQB) - Oeiras, Portugal \\ ${ }^{4}$ Departamento de Química - Universidade de Évora, Portugal \\ ${ }^{5}$ Departamento de Biologia - Universidade de Évora, Portugal
}

\begin{abstract}
In order to study the effects of tannins at histomorphological level, mice were either fed with three structurally different types of tannins (tannic acid, chestnut, and quebracho) or treated with isoproterenol, during 10 days. Acini of parotid and submandibular glands increased significantly, being the increase higher for parotid compared to submandibular glands, and higher in the quebracho compared with the other tannin groups. Sublingual acinar size also increased after tannin consumption, by opposition to isoproterenol-treated animals. The results present evidences that the effects produced by tannins are dependent on their structure.
\end{abstract}

Keywords: mice, condensed tannin, hydrolysable tannin, isoproterenol, salivary glands, histology

\section{RESUMO}

Estudaram-se as alterações morfológicas das glândulas salivares, induzidas por taninos, em camundongos. Os animais foram distribuídos em grupos e tratados com três diferentes tipos estruturais de taninos (ácido tânico, chestnut e quebracho - adicionados à ração) ou isoproterenol via intraperitoneal, durante 10 dias. Os ácinos das glândulas parótida e submandibulares aumentaram significativamente de tamanho, sendo o incremento maior para a parótida que para as submandibulares, e maior com o quebracho comparado com o provocado pelos outros taninos. Os ácinos das glândulas sublinguais também aumentaram após o consumo de taninos em relação aos ácinos dos animais tratados com isoproterenol. Os resultados apresentam evidencias de que os efeitos produzidos pelos taninos dependem de sua estrutura.

Palavras-chave: camundongo, tanino condensado, tanino hidrolisável, isoproterenol, glândulas salivares, histologia

Recebido em 15 de outubro de 2009

Aceito em 2 de agosto de 2010

*Autor para correspondência (corresponding author)

E-mail: fcs@uevora.pt 


\section{INTRODUCTION}

Chronic administration for several days of isoproterenol, an agonist of autonomic sympathetic nervous system, elicits massive growth of salivary glands. A considerable number of investigators observed an acinar enlargement of parotid and submandibular gland produced by isoproterenol in rodents (Barka and Burke, 1977; Chisholm and Adi, 1995; Vugman and Hand, 1995). These morphological changes have been associated to an increased synthesis and secretion of salivary proteins, namely alphaamylase and salivary proline rich proteins (Robinovitch et al., 1977; López Solís, 1989; López Solís et al., 1987, 1990, 1993; Vugman and Hand, 1995).

Parotid and submandibular glands weight increase was also referred for rats (Mehansho et al., 1983; Jasman et al., 1994) and mice (Mehansho et al., 1985) consuming tannins, being this increase linear with increasing amounts of condensed tannins (Jansman et al., 1994).

A few reports have shown that feeding rats and mice on tannin containing diets can produce salivary gland enlargement, similarly to what occurs with isoproterenol administration (Mehansho et al., 1983, 1985, 1987; HumphreysBeher et al., 1987; Jansman et al., 1994). The objectives of this work were to study the changes on the morphometric parameters of the three pairs of major salivary glands at histological level and to compare the effects produced by different types of stimulations: hydrolysable tannins and condensed tannins (quebracho) and the sympathomimetic agonist isoproterenol.

\section{MATERIALS AND METHODS}

For each experiment, four-week-old inbred Balb/c mice, were obtained from the licensed bioterium of Instituto Gulbenkian de Ciência (Oeiras, Portugal). The animals were housed in mice cages, type IV (Techniplast) (five mice per cage), according to European Union (EU) recommendations and revision of Appendix A of European Convention for the Protection of Vertebrate Animals used for Experimental and other Scientific Purposes (ETS $\mathrm{N}^{\circ}$ 123) and maintained on a 12:12h light/dark cycle, at a constant temperature of $22^{\circ} \mathrm{C}$, with ad libitum access to water and to a standard diet with $21.86 \%$ crude protein (dry basis) in the form of pellets (RM3A-P; Dietex International, UK). All procedures involving the animals were approved by the scientific committee, supervised by a Federation of European Laboratory Animal Science Association trained scientist and conforming to the regulations of the Portuguese law (Portaria 1005/92), following European Union Laboratory Animal Experimentation Regulations.

Animals were submitted to a 7-day acclimation period to minimize stress associated with transportation. This period was followed by a 7day pretrial period to allow adaptation to the ground diet using during the experimental period. The standard pellet diet was daily ground with a blender to obtain a meal with visibly homogeneous fine-sized particles. Before the feeding-trial period, animals were individually weighed and allocated to the experimental groups, each group had no significant differences in body mass $(20.47 \pm 1.27$ for animals used in the first experiment and 23.29 \pm 3.22 for animals used in the second experiment).

Immediately after the pretrial period, the 10-day "administration" period started being followed by a 9-day "recovery" period. A total of 33 female mice were distributed in three experimental groups. The control group $(n=5)$ received a tannin-free diet, the same standard ground diet as in the pre-trial period, and were daily intraperitoneally injected with $1 \mathrm{~mL}$ of a saline solution ( $\mathrm{NaCl} 0.9 \%$ ). The tannic acid group $(n=14)$ received the standard ground diet plus tannic acid (hydrolysable tannin - Merck, Darmstadt, Germany) added to obtain a mixture with $3 \mathrm{~g}$ tannin/100g (3\%) wet weight of the standard diet. The animals from this group received the same daily saline injection described for control group. The isoproterenol group $(n=14)$ received the same standard ground diet, as the control group, but were daily injected with $50 \mu \mathrm{g} / \mathrm{g}$ live weight of isoproterenol ( $\mathrm{dl}$ isoproterenol-HCl - Sigma, St. Louis, USA), dissolved in $1 \mathrm{~mL}$ of saline solution $(\mathrm{NaCl} 0.9 \%)$. At day 11, five animals from each group were intraperitoneally injected with anesthetic (xylazine/ketamine) (Xylazine hydrochloride Bayer, Leverkusen, Germany; Ketamine hydrochloride, Pfizer Inc., Groton, CT, USA.) 
and euthanized with an overdose. The three main salivary glands were dissected, briefly washed with phosphate buffer $0.1 \mathrm{M}, \mathrm{pH} 7.4$, and fixed in $10 \%$ neutral buffered formalin. After embedding the fixed salivary glands in paraffin wax, using routine procedures, a series of sections of $5 \mu \mathrm{m}$ thick were cut with a microtome, and the slides were stained with Hematoxylin and Eosin (H\&E).

The remaining animals from tannic acid and isoproterenol groups initiated the "recovery period", which consisted in the absence of stimulation, either by isoproterenol or tannic acid. At days 3, 6, and 9 after stimuli cessation, three animals from each group were euthanized, and salivary glands dissected, as previously described, to examine the progression in the "regression" of salivary glands. During all the experimental period, food and water were provided ad libitum and the diets were daily prepared with a blender, as described for the pretrial period. The glands were always collected between 9:00 and 12:00am to avoid circadian variations.

Twenty male mice were distributed in four groups: control $(n=5)$, tannic acid $(n=5)$, chestnut $(n=5)$, and quebracho $(n=5)$. Tannins were added to the powdered standard diet to obtain a mixture with $6 \mathrm{~g}$ tannin $/ 100 \mathrm{~g}(6 \%)$ wet weight of the standard diet [tannic acid; chestnut extract (Tannino C) (SilvaChimica SRL, San Michele di Mondovì, Italy); $77 \%$ of hydrolysable tannins; quebracho extract (Tupafin-Ato) (SilvaChimica SRL, San Michele di Mondovì, Italy); $72 \%$ of condensed tannins]. At day 11, the animals were euthanized and salivary glands removed as described for the first experiment.

The sections of salivary glands were observed at light microscopy with a Nikon Eclipse 600 microscope (Nikon, Kanagawa, Japan). For each animal, ten digital pictures from random areas, of each salivary gland, were collected with a Nikon DN100 camera (Nikon, Kanagawa, Japan ). For each animal, the areas and perimeters of a minimum of 100 acini from parotid, submandibular, and sublingual glands and a minimum of 100 submandibular granular convoluted tubules (transverse sections) were randomly chosen and measured by SigmaScan Pro 5.0 software (SPSS, Chicago, USA). Only the histological structures whose limits were clear defined were considered for measure.

Histomorphometric data were tested for normality and homocedaticity by KolmogorovSmirnov and Levene tests, respectively, and oneway ANOVA was performed. When normality was not achieved for each treatment, the non-parametric Kruskal-Wallis $\mathrm{Z}$ multiple comparison procedure was used. For normally distributed data, the means significantly different to post-hoc comparison (Turkey-Kramer test) were regarded as significantly different when $\mathrm{P}<0.05$. All statistical analysis procedures were performed by NCSS 2001 software package (NCSS, Kaysville, UT, USA).

\section{RESULTS}

Histomorphological analysis showed that both isoproterenol and tannic acid induced changes in female mice parotid and submandibular salivary glands. At acinar level (Table 1), isoproterenol treatment resulted in a great enlargement of parotid acinar (about 5-fold increase) and submandibular acinar (about 3-fold increase) areas, when compared with tannic acid consumption that only increased in a less pronounced way the parotid acinar area (about 2fold increase). In submandibular glands, isoproterenol treatment also produced a significant increase in the perimeter of seromucous acini (about 3-fold), whereas tannic acid did not produce changes in these submandibular structures. No changes were observed in acinar sublingual glands after both treatments (Table 1).

Once the stimulation was withdraw, the glandular dimensions started to decrease. At three days following the cessation of tannin consumption, the size of parotid acini had returned to control values, whereas for the individuals treated with isoproterenol such a recovery was not complete even nine days after treatment cessation. Nevertheless, at the $3^{\text {rd }}$ day of recovery period, a significant reduction was already observed for the animals that received isoproterenol (about half of the size than at the $11^{\text {th }}$ day trial) and at the sixth day the parotid acinar size from these animals was similar to the one from the animals that received 3\% tannic 
acid for ten days. At the $3^{\text {rd }}$ day of recovery period, it was possible to observe apoptotic bodies in some acinar cells of the animals that received isoproterenol, suggesting that apoptosis may be a mechanism involved in the deletion of acinar cells and in the returning of parotid glands to normal levels.

According to qualitative evaluation, it was evident that the amount of visible granular convoluted tubules (GCT) was considerably decreased in the animals treated with isoproterenol for ten days. In these, GCT appeared scattered among the hypertrophic acinar cells. However, for the well limited GCT measured, no significant changes in the dimensions were obtained (Table 2). With the stop of isoproterenol administration, the visible amount of these structures seemed to start returning to control levels, since the $3^{\text {rd }}$ day after the last isoproterenol administration.

All the three structurally different tannins used in this experiment produced an enlargement in parotid, submandibular, and sublingual acini. The enlargement in parotid acini was significantly higher for the animals consuming quebracho tannin (almost a 3-fold increase in acinar area, compared with control group) than for the groups consuming the same amount of tannic acid or chestnut tannins (2-fold increase, compared with control group) (Table 3). However, the consumption of tannins had no effect on the size of submandibular GCT (Table 4) and no such pronounced differences in the distribution of these structures, as the ones observed for isoproterenol treatment in the first experiment, seemed to occur.

Table 1. Acinar structures of salivary glands of mice $(n=5)$ according to treatments (Mean \pm SD)

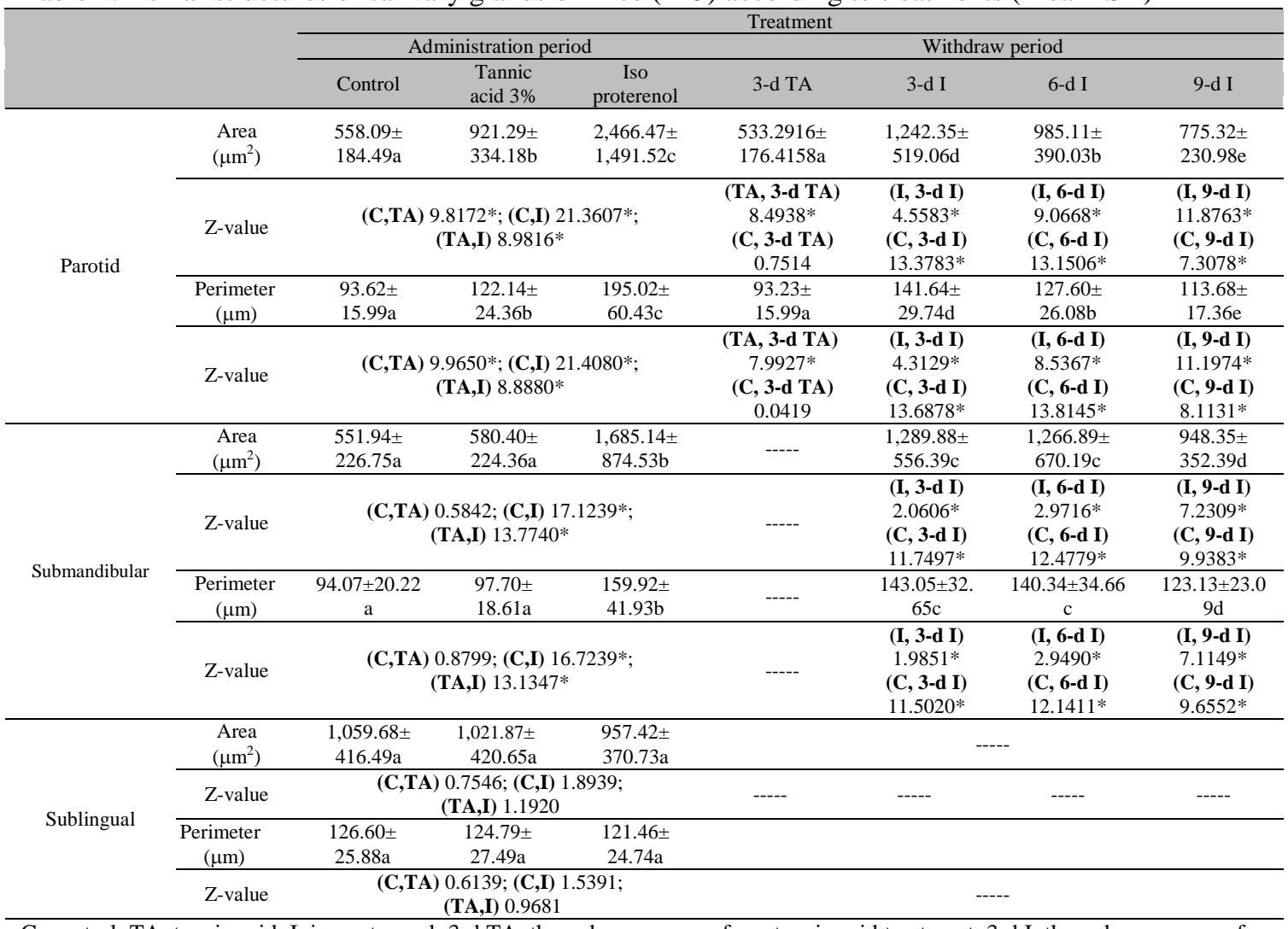

C: control; TA: tannic acid; I: isoproterenol; 3-d TA: three days recovery from tannic acid treatment; 3-d I: three days recovery from isoproterenol treatment; 6-d I: six days recovery from isoproterenol treatment; 9-d I: nine days recovery from isoproterenol treatment. Same lowercase letters indicate no differences among the values of the columns in the same line (Kruskal-Wallis $\mathrm{Z}$ multiple comparison procedure). *Differences are significant for Z-value $>1.9$. 
Morphological alterations...

Table 2. Submandibular granular convoluted tubules (GCT) of mice $(n=5)$ according to treatments (Mean \pm SD)

\begin{tabular}{|c|c|c|c|c|c|c|}
\hline & \multicolumn{3}{|c|}{ Treatment } & \multicolumn{3}{|c|}{ Z-value* } \\
\hline & Control & Tannic acid & Isoproterenol & $\mathrm{C}, \mathrm{TA}$ & $\mathrm{C}, \mathrm{I}$ & TA, I \\
\hline Area $\left(\mu \mathrm{m}^{2}\right)$ & $\begin{array}{c}831.39 \pm \\
467.59\end{array}$ & $\begin{array}{c}795.07 \pm \\
351.62\end{array}$ & $\begin{array}{c}789.71 \pm \\
509.90\end{array}$ & 0.0726 & 0.9107 & 0.8682 \\
\hline $\begin{array}{l}\text { Perimeter } \\
\qquad(\mu \mathrm{m})\end{array}$ & $\begin{array}{c}124.44 \pm \\
41.68\end{array}$ & $\begin{array}{c}118.29 \pm \\
33.69\end{array}$ & $\begin{array}{c}112.55 \pm \\
39.53\end{array}$ & 0.4174 & 1.5676 & 1.1959 \\
\hline
\end{tabular}

Table 3. Acinar structures of salivary glands of mice $(n=5)$ according to treatments (Mean \pm SD)

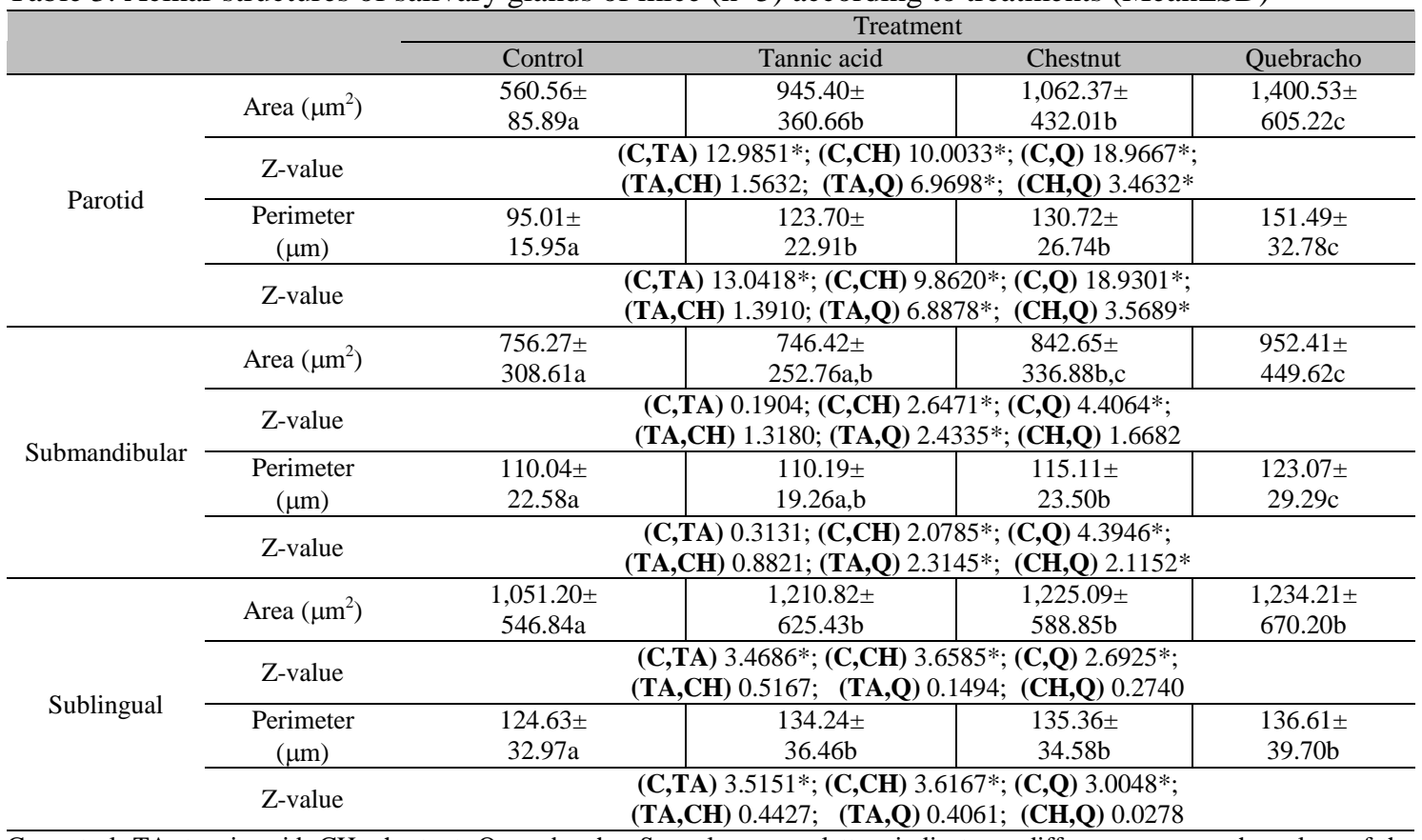

C: control; TA: tannic acid; $\mathrm{CH}$ : chestnut; Q: quebracho. Same lowercase letters indicate no differences among the values of the columns in the same line (Kruskal-Wallis Z multiple comparison procedure). *Differences are significant for Z-value $>1.96$.

Table 4. Submandibular granular convoluted tubules (GCTs) of mice $(n=5)$ according to treatments $(\mathrm{Mean} \pm \mathrm{SD})$

\begin{tabular}{|c|c|c|c|c|c|}
\hline & \multicolumn{4}{|c|}{ Treatment } & \multirow{2}{*}{ Z-value } \\
\hline & Control & Tannic acid & Chestnut & Quebracho & \\
\hline Area $\left(\mu \mathrm{m}^{2}\right)$ & $\begin{array}{c}3,566.50 \pm \\
1,933.80\end{array}$ & $\begin{array}{c}3,343.44 \pm \\
1,751.26\end{array}$ & $\begin{array}{c}3,817.33 \pm \\
2195.39\end{array}$ & $\begin{array}{c}3,739.74 \pm \\
2,416.27\end{array}$ & $\begin{array}{c}\text { (C,TA) } 1.1472 \text { (C,CH) } 1.1010 \\
\text { (C,Q) } 0.0274 \text { (TA,CH) } 1.9153 \\
(\mathbf{T A , Q )} 0.8832(\mathbf{C H}, \mathbf{Q}) 0.9416\end{array}$ \\
\hline Perimeter $(\mu \mathrm{m})$ & $\begin{array}{c}235.84 \pm \\
75.41\end{array}$ & $\begin{array}{c}227.15 \pm \\
67.83\end{array}$ & $\begin{array}{c}245.57 \pm \\
81.13\end{array}$ & $\begin{array}{c}242.39 \pm \\
92.79\end{array}$ & $\begin{array}{c}\text { (C,TA) } 1.2902 \text { (C,CH) } 1.4129 \\
\text { (C,Q) } 0.0811 \text { (TA,CH) } 2.3145^{*} \\
\text { (TA,Q) } 0.9471(\mathbf{C H}, \mathbf{Q}) 1.2463\end{array}$ \\
\hline
\end{tabular}

\section{DISCUSSION}

In the present study, it was observed that both isoproterenol and tannins increase the size of the acini from parotid and submandibular glands and that these changes are induced by both hydrolysable and condensed tannins. Selye et al. (1961) were the first authors reporting that long- 
term administration of isoproterenol elicits massive growth of parotid and submandibular glands in rodents. This is due to the stimulation of DNA synthesis and cell proliferation (hyperplasia) in the first 2-3 days, followed by an enlargement of cell size (hypertrophy) in the next days (Chisholm and Adi, 1995; Ochiai et al., 2002), what may also reflect the increase in number and size of secretory granules (Matsuura and Hand, 1991; Matsuura and Suzuki, 1997). After the stop of stimulation, it is observed a regression of the enlarged tissue. Apoptosis (Chisholm and Adi, 1995) and, at a fewer extent necrosis (Ochiai et al., 2002) seem to be responsible for this involution.

Apparently, the effect of isoproterenol treatment was stronger than the one from tannic acid, although statistical comparisons with chestnut and quebracho groups were not performed, due to the use of different genders in each experiment. The increases in salivary acinar areas produced by isoproterenol are concordant with the ones referred in bibliography (Onofre et al., 1997; Ochiai et al., 2002).

The mouse submandibular gland possesses two morphologically and biochemically distinct exocrine compartments with different modes of secretory activity: acini and granular convoluted tubules (GCT). Both were analyzed in the present study. In what concerns seromucous acini, an increase in their dimensions was induced both by isoproterenol, in the first experiment, and chestnut and quebracho tannins, in the second experiment. In submandibular acini, differences were not observed after tannic acid treatment, suggesting differences among types of tannins in their action at submandibular acinar level. Studies reporting differences among the different structural types of tannins and their effects in salivary gland weight/structure were not found. However, it was observed in ruminants, that different types of tannins produce different effects: some species are tolerant to a structural type, but not to a different one, whereas others seem to tolerate all structural types (Clauss et al., 2003). It had been proposed to be due to amounts and types of tannins usually found in the regular diets (McArthur et al., 1995). For rats, it was referred that condensed tannins from grape seed and quebracho produced significant effect on growth depression and feed intake, whereas hydrolysable tannins were devoid of such a deleterious effect (Joslyn and Glick, 1969).

Based on morphological characteristics (Ochiai et al., 2002), apoptotic cells were observed in the animals that received isoproterenol, by day 3 post-treatment. Apoptosis were already proposed to account for cell deletion in salivary glands enlarged by isoproterenol (Chisholm and Adi, 1995; Ochiai et al., 2002). Nine days postisoproterenol administration, the salivary glands had not the control values of size, suggesting that a higher period of time is necessary for a full recovery, going in accordance with other studies (Ochiai et al., 2002). The recovery from tannin treatment was quicker. The lower growth induced by these compounds may explain it.

The GCT are specialized types of secretory canal that lies between the intercalated and striated ducts and are well-marked in the submandibular glands of rodents (Pinkstaff, 1980; Tandler, 1993). Systemic application of isoproterenol for a period of ten days did not result in changes in the dimension of these structures. Chisholm and Adi (1995) also reported an absence of cell proliferation in these glandular structures after isoproterenol treatment.

Isoproterenol is a powerful $\beta$-adrenergic agonist, which is active in the stimulation of $\beta 1$ - and $\beta 2$ adrenergic responses (Zaagsma and Nahorski, 1990). The submandibular acini and GCTs were surrounded by both an adrenergic and a cholinergic plexus. Whereas acinar exocytotic secretion is greatly stimulated through $\beta$ adrenergic receptors, the granular secretion from the convoluted tubules is predominantly stimulated through $\alpha$-adrenergic receptors (Hosoi et al., 1978; Vreugdenhil et al., 1980). This may be the explanation for the great effect that isoproterenol had on acinar cells rather than on GCT cells. According with studies showing that systemic administration of isoproterenol and topical administration of tannic acid to mice mouths both resulted in the production of a particular group of polypeptides (Gho et al., 2007), it is possible to think that tannin consumption has an effect at sympathetic nervous level, resulting in the activation of adrenergic receptors from the $\beta$-, rather that the $\alpha$-type. This explains the lack of effect of tannins in GCT observed in this work. Despite all the 
similar effects produced by tannins and isoproterenol, in what concerns sublingual glands, only tannins induced an increase in the acinar dimensions. This difference points to the possibility of tannins do not act exclusively through beta adrenergic receptor stimulation, inversely to isoproterenol.

\section{CONCLUSIONS}

Tannic acid and chestnut, the two hydrolysable tannins, produced a lower increase in parotid acinar size than the condensed tannin quebracho. The mice and rat parotid gland enlargement induced by isoproterenol had been associated to the secretion of proline-rich salivary proteins (Mehansho et al., 1983; 1985; Gho et al., 2007). The production of these proteins were also observed after tannin consumption. The results present evidences that the effects produced by tannins are dependent on their structure. It can be speculated that the different structural types of tannins have different "negative" effects on the animal, and condensed tannin consumption results in a greater need of tannin-binding proteins than hydrolysable tannins consumption.

\section{ACKNOWLEDGEMENTS}

This work was supported by the POCTI FCTCVT/33039/99-00 scientific project. Elsa Lamy acknowledge a $\mathrm{PhD}$ grant from the $3^{\circ}$ Quadro Comunitário de Apoio of FCT-Fundação para a Ciência e a Tecnologia of the Ministério da Ciência Tecnologia e Ensino Superior, Portugal. We acknowledge the generous offer of Tupafin Ato from the Silva Chimica Company (Italy).

\section{REFERENCES}

BARKA, T.; BURKE, G.T. Secretory behaviour of hypertrophic and hyperplastic salivary gland. Histochem. J., v.9, p.453-466, 1977.

CHISHOLM, D.M; ADI, M.M. Cell proliferation and apoptosis in isoprenaline-induced sialosis in the rat submandibular glands. Int. J. Exp. Pathol., v.76, p.263-269, 1995.

CLAUSS, M.; LASON, K.; GEHRKE, J. et al. Captive roe deer (Capreolus capreolus) select for low amounts of tannic acid but not quebracho: fluctuation of preferences and potential benefits.
Comp. Biochem. Physiol. B Biochem. Mol. Biol., v.136, p.369-382, 2003.

GHO, F.; PEÑA-NEIRA, A.; LÓPEZ-SOLÍS, R.O. Induction of salivary polypeptides associated with parotid hypertrophy by gallotannins administered topically into the mouse mouth. J. Cell. Biochem., v.100, p.487498, 2007.

HOSOI, K.; AOYAMA, K.; UEHA, T. Regulation of the secretory process of granular components from the convoluted tubular cells of the mouse submandibular gland. J. Dent. Res., v.57, p.87-90, 1978.

HUMPHREYS-BEHER, M.G.; ROBINSON, G.D.; AL-ZAHID, S. et al. Neural and dietary modulation of proline-rich protein and 4galactosyltransferase biosynthesis in rat parotid glands. Arch. Oral Biol., v.32, p.573-578, 1987.

JANSMAN, A.J.; FROHLICH, A.A.; MARQUARDT, R.R. Production of proline-rich proteins by the parotid glands of rats is enhanced by feeding diets containing tannins from Faba beans (Vicia faba L.). J. Nutr., v.124, p.249-258, 1994.

JOSLYN, M.A.; GLICK, Z. Comparative effects of gallotannic acid and related phenolics on the growth of rats. J. Nutr., v.98, p.119-126, 1969.

LÓPEZ SOLÍS, R.O. Secretory character of a group of isoproterenol-induced polypeptides in mouse parotid glands. J. Cell. Physiol., v.141, p.660-666, 1989.

LÓPEZ SOLÍS, R.O.; ALLIENDE, C.; GONZÁLEZ, J. et al. Changes in the polypeptide composition related to the growth response in chronically isoproterenol-stimulated mouse parotid glands. Biochim. Biophys. Acta, v.930, p.463-469, 1987.

LÓPEZ SOLÍS, R.O.; GONZÁLEZ, M.J.; CASTILlO, L. et al. Transcriptional and posttranscriptional control in synthesis of growth marker polypeptides in mouse parotids. Am. J. Physiol., v.265, p.G514-G520, 1993.

LÓPEZ SOLÍS, R.O.; MIRANDA, D.; WILSON, D.M. et al. Effect of isoproterenol analogs on the polypeptide composition of mouse parotid glands: relationship to enhanced growth. Biochim. Biophys. Acta, v.1054, p.311316, 1990. 
McARTHUR, C.; SANSON, G.D.; BEAL, A.M. Salivary proline-rich proteins in mammals: role in oral homeostasis and counteracting dietary tannins. J. Chem. Ecol., v.21, p.663-691, 1995.

MATSUURA, M.; HAND, A.R. Quantitative immunocytochemistry of rat submandibular secretory proteins during chronic isoproterenol administration and recovery. J. Histochem. Cytochem., v.39, p.945-954, 1991.

MATSUURA, S.; SUZUKI, K. Immunohistochemical analysis of DNA synthesis during chronic stimulation with isoproterenol in mouse submandibular gland. J. Histochem. Cytochem., v.45, p.1137-1145, 1997.

MEHANSHO, H.; ANN, D.K.; BUTLER, L.G. et al. Induction of proline-rich proteins in hamster salivary glands by isoproterenol treatment and an unusual growth inhibition by tannins. J. Biol. Chem., v.262, p.12344-12350, 1987.

MEHANSHO, H.; CLEMENTS, S.; SHEARES, B.T. et al. Induction of proline-rich glycoprotein synthesis in mouse salivary glands by isoproterenol and by tannins. J. Biol. Chem., v.260, p.4418-4423, 1985.

MEHANSHO, H.; HAGERMAN, A.; CLEMENTS, S. et al. Modulation of proline-rich protein biosynthesis in rat parotid glands by sorghums with high tannin levels. Proc. Natl. Acad. Sci. USA, v.80, p.3948-3952, 1983.

OCHIAI, S.; HASHIMOTO, S.; SHIMONO, M. Acinar cell hypertrophy, proliferation and cell death in rat submandibular glands induced by long-term isoproterenol administration. Acta Histochem. Cytochem., v.35, p.383-393, 2002.
ONOFRE, M.A.; DE SOUZA, L.B.; CAMPOS JR, A. et al. Stereologic study of acinar growth in the rat parotid gland induced by isoproterenol. Arch. Oral Biol., 42, p.333-338, 1997.

PINKSTAFF, C.A. The cytology of salivary glands. Int. Rev. Cytol., v.63, p.141-261, 1980.

ROBINOVITCH, M.R.; KELLER, P.J.; JOHNSON, D.A. et al. Changes in rat parotid salivary proteins induced by chronic isoproterenol administration. J. Dent. Res., v.56, p.290-303, 1977.

SELYE, H.; VEILLEUX, R.; CANTIN, M. Excessive stimulation of salivary gland growth by isoproterenol. Science, v.133, p.44-45, 1961.

TANDLER, B. Structure of the duct system in mammalian major salivary glands. Microsc. Res. Tech., v.26, p.57-74, 1993.

VREUGDENHIL, A.P.; DE LANGE, G.L.; NIEUW AMERONGEN, A.V. et al. Morphological changes in the salivary glands upon stimulation by receptor-selective agonists. II. Submandibular glands of the mouse. J. Biol. Buccale, v.8, p.73-86, 1980.

VUGMAN, I.; HAND, A.R. Quantitative immunocytochemical study of secretory protein expression in parotid glands of rats chronically treated with isoproterenol. Microsc. Res. Tech., v.31, p.106-117, 1995.

ZAAGSMA, J.; NAHORSKI, S.R. Is the adipocyte $\beta$-adrenoceptor a prototype for the recently cloned atypical " $\beta 3$-adrenoceptor"? Trends Pharmacol. Sci., v.11, p.3-7, 1990. 